\title{
Capturing the Voice of the Customer for Paper-notebook Product Development
}

\author{
Puteri Annisa Tsamrotul Fuadah and Eko Agus Prasetio
}

\begin{abstract}
Paper-notebook is one of the crucial school equipment and always needed. A study also found out that despite the widespread use of information and communication technology (ICT), there is a significant number of students who prefer to use a paper-based resource for writing and reading. The use of paper-notebook products also affected by the youngsters (productive age), and it estimated that $65 \%$ of the total population in Indonesia is in a productive period. Indonesia's demand for paper-notebook also keeps developing. To optimize the market opportunity regarding paper-notebook product, the innovation of product that matches the needs of the local and potential markets is crucial. The understanding and fulfillment of customers' needs are one of the drivers for better business results; a project with high-quality marketing actions, which includes capturing the Voice of the Customer (VOC), double the success rates and have $70 \%$ higher market shares than those projects with an inadequate approach. Hence, this researcher aimed to identify customer needs regarding paper-notebook by capturing the Voice of the Customer then process it into a paper-notebook design based on customer preference.
\end{abstract}

Index Terms-Customer Needs, Customer Preferences, Paper-notebook, the Voice of the Customer (VOC)

\section{INTRODUCTION}

The Voice of the Customer process has relevant outputs and benefits for product developers. It provides a detailed understanding of the customer's requirements; a common language for the team going forward in the product development process, an essential input for the setting of appropriate design specifications for the new product or service, and a highly useful springboard for product innovation. Gathering the Voice of the Customer is a vital part of the new product development process. It forms a solid basis for design and marketing decisions from concept development through product launch [12]. Also, a study by [33] found that the customers' voice has the most substantial impact on new product development. The research shows that the organizations should focus on the concept to understand the customer and in turn develop product or services that meet consumer needs and wants better than competitors in resulting they will earn more significant revenue.

In addition, paper-notebook clarified as a book of plain paper or paper with lines, for writing on [3]. Moreover, the paper notebook becomes the product and the main object that researched. Thus, this research aimed to fulfill these objectives:

1. To find out the paper notebook features based on captured the Voice of the Customer (VOC).
2. To create a new product design for paper notebook based on customer preference.

\section{METHODOLOGY}

\begin{tabular}{|c|c|c|c|c|}
\hline FOCUS & COLLECT & INTERPRET & STRUCTURE & QUANTIFY \\
\hline $\begin{array}{l}\text { Set the } \\
\text { respondents' } \\
\text { segment }\end{array}$ & $\begin{array}{c}\text { Semi- } \\
\text { structured } \\
\text { Interview }\end{array}$ & $\begin{array}{l}\text { The Voice of } \\
\text { the Customer } \\
\text { Table (VOCT) }\end{array}$ & $\begin{array}{l}\text { 1. Affinity Diagram } \\
\text { 2. Interrelationship } \\
\text { Diagraph } \\
\text { 3. Tree Diagram }\end{array}$ & $\begin{array}{l}\text { Conjoint } \\
\text { Analysis }\end{array}$ \\
\hline
\end{tabular}

Fig. 1 Research Methodology

Based on the book by [37], there are seven steps to capture and process the Voice of the Customer (VOC). The seven steps consist of focus, collect, interpret, structure, quantify, verify, and deploy. Each step must be done sequentially. Specifically, this research employed five out of seven steps starting from focus until quantify. Besides, each step uses a tool to complete the process. In the focus step, the researcher set the segment of respondents based on the current potential market segment and the active user of paper-notebook. Based on the pre-preliminary research, the respondents of this research are a female college student (16-25 years old) that domiciled in Bandung that uses papernotebook in daily life and often buys it. The second step is to collect data from the respondents. The researcher utilized the exploratory study to seek new insights and to ask questions and to assess phenomena in a new light [34]. Hence, to collect the data for this research, the researcher utilized the mixed-method research and used both quantitative and qualitative data collection techniques and analyze after the other (sequential) but does not combine them. To get detailed data about customer needs, the researcher collects the qualitative data first by interview. To get more understanding about the problem and get unexpected insight or information from the interviewee, the researcher utilized the semi-structured interview. And in deciding who will be interviewed, the researcher uses nonprobability sampling by purposive or judgmental sampling and self-selection sampling. The number of semi-structured interviews was ten people since [11] state that the ideal amount of respondents or informants to make the qualitative approach are ten people.

To interpret the data, the researcher utilized the Voice of the Customer Table (VOCT) and continue structuring the data by the Affinity Diagram, the Interrelationship Diagraph, and Tree Diagram. Moreover, to quantify the data in order to obtain statistically valid data, further research did by surveying by questionnaire [8]. The survey will look for the data from the customer about their preferred features of a paper paper-notebook attributes that listing based on the data from the interview. The result of this questionnaire is the data of most preferred features by the customer that will be analyzed by conjoint analysis - one hundred and ninetysix data collected from the same segment of semi-structured 
interview respondents - then utilized Descriptive Analysis and Conjoint Analysis to analyze the data qualitatively.

\section{DATA COLLECTION}

\section{A. Voice of the Customer Table (VOCT)}

TABLE 1: THE VOICE OF THE CUSTOMER TABLE

\begin{tabular}{|c|c|c|c|c|c|}
\hline \multicolumn{6}{|c|}{$\begin{array}{c}\text { Interviewee: Ummu Qonitah, } 22 \text { Years Old - Last Year } \\
\text { Student }\end{array}$} \\
\hline $\begin{array}{l}\text { Customer Verbatim } \\
\text { (Indonesian) }\end{array}$ & $\begin{array}{l}\text { Re-worded } \\
\text { Data }\end{array}$ & $\begin{array}{l}\mathrm{N} \\
\mathrm{e} \\
\mathrm{e} \\
\mathrm{d}\end{array}$ & \begin{tabular}{l|} 
\\
$o$ \\
1 \\
$u$ \\
$\mathrm{t}$ \\
$\mathrm{i}$ \\
$\mathrm{o}$ \\
$\mathrm{n}$
\end{tabular} & $\begin{array}{l}\mathrm{F} \\
\mathrm{e} \\
\mathrm{a} \\
\mathrm{t} \\
\mathrm{u} \\
\mathrm{r} \\
\mathrm{e}\end{array}$ & $\begin{array}{l}\mathrm{O} \\
\mathrm{t} \\
\mathrm{h} \\
\mathrm{e} \\
\mathrm{r}\end{array}$ \\
\hline $\begin{array}{l}\text { "Kalau beli sesuatu } \\
\text { warna yang gelap itu } \\
\text { kurang gitu, mening } \\
\text { sekalian yang cetar." }\end{array}$ & $\begin{array}{l}\text { a. Dislike a } \\
\text { dark color. }\end{array}$ & & & $\sqrt{ }$ & \\
\hline $\begin{array}{l}\text { "Sebenernya aku suka } \\
\text { titik-titik yang polosan } \\
\text { gini. Karena gak ada } \\
\text { garisnya jadi lebih beabs } \\
\text { aja. Kalau titik-titik ini } \\
\text { gak terlalu ngatur gitu, } \\
\text { dia funsginya membantu } \\
\text { tapi gak mengatur." }\end{array}$ & $\begin{array}{l}\text { a. Prefer a } \\
\text { dotted } \\
\text { paper. } \\
\text { b. Dislike a } \\
\text { striped } \\
\text { paper. }\end{array}$ & $\sqrt{ }$ & & $\sqrt{ }$ & \\
\hline
\end{tabular}

Interviewer: Puteri Annisa

Product(s): Paper-Notebook

Market Segment(s): College Student, Female

Voice of the Customer Table (VOCT) is a method to gain a more in-depth understanding of customer needs by expanding current needs through the use of the "who, what, where, when, why, and how" questions. The VOCT is a tool to explore customer needs into to derive more needs of the exciting quality variety. The table collects the customer verbatim based on the exact words said by the customer and elaborates it into the re-worded data. Then the researcher qualified the verbatim whether it is an internal data or can be shared to an external party. The researcher then classified whether the verbatim is a 'need', 'solution', 'feature', or any other type of information [37]. The VOCT consists of a long table that processed from the captured voice of the customer from ten respondents. Thus, the researcher only put one VOCT sample from one respondent.

The result from the interview are diverse; however based on the result from VOCT, eight respondents bought a papernotebook when they need it. They will need it when the current paper-notebook is running out. Moreover, all of the respondents use paper-notebook in daily life to write many important things such as college material, shopping list, todo-list, organizations related, thesis related, and any other important activities in daily life. Hence they have several paper-notebook to write different importance. However, some of the respondents only have one paper-notebook to write all of the things in one book hence they divided papernotebook into several parts based on its importance. All of the respondents always bring paper-notebook everywhere they go. Hence they want a paper-notebook that easy to carry and fit in their bag.

Many consideration to buy a paper-notebook stated by respondents such as cover material and design, price, paper, and size. However, most of the respondents chose cover and paper as their critical consideration to buy paper-notebook. Eight respondents consider paper-notebook's design and material as their determinant to buy a paper-notebook. Eight respondents prefer a hardcover, while two respondents prefer softcover. Also, all respondents want to have a cute cover design. Six respondents also want to have a simple cover design that does not have any excessive design.

From the diverse result of VOCT, most of the respondents stated about their consideration regarding cover design such as cover material, the features of paper-notebook, the paper type, and their experience regarding the current papernotebook they use. They stated about the things they like and dislike from their current paper-notebook.

\section{B. Affinity Diagram and Interrelationship Diagraph of VOC}

\begin{tabular}{|c|c|}
\hline $\begin{array}{l}\text { Paper Type } \\
\end{array}$ & \begin{tabular}{|l|} 
Cover Type \\
\end{tabular} \\
\hline $\begin{array}{l}\checkmark \text { Plain paper to be able to } \\
\text { write freely. } \\
\checkmark \text { Striped paper to be able to } \\
\text { write neatly. } \\
\checkmark \text { Dotted paper to be able to } \\
\text { draw. } \\
\checkmark \text { Yellowish paper. } \\
\checkmark \text { Dislike a heavy paper- } \\
\text { notebook }\end{array}$ & $\begin{array}{l}\checkmark \text { Hardcover; stronger and } \\
\text { durable, } \\
\checkmark \text { Softcover; light } \\
\checkmark \text { Precise size } \\
\checkmark \text { Stitched binding } \\
\checkmark \text { Glued binding } \\
\checkmark \text { Spiral binding } \\
\checkmark \text { A5 size }\end{array}$ \\
\hline Cover Design & Features \\
\hline $\begin{array}{l}\checkmark \text { Self-branding } \\
\checkmark \text { Suitable with personality } \\
\checkmark \text { Dark color } \\
\checkmark \text { Soft color } \\
\checkmark \text { Limited and different } \\
\text { from others } \\
\checkmark \text { Cute design } \\
\checkmark \text { Quotes design as a } \\
\text { reminder } \\
\checkmark \text { Calm color }\end{array}$ & $\begin{array}{ll}\checkmark & \text { Strap to make the paper- } \\
\text { notebook locked } \\
\checkmark & \text { Always divide the paper- } \\
\text { notebook into several } \\
\text { sections } \\
\checkmark & \text { Pen holder to keep the } \\
\text { pen attached } \\
\checkmark & \text { Multi-function } \\
\checkmark & \text { File holder to keep } \\
\text { important paper }\end{array}$ \\
\hline
\end{tabular}

Fig. 2. Affinity Diagram and Interrelationship Diagraph

The Affinity Diagram is a bottom-up clustering technique to group large amounts of language or qualitative data such as VOC verbatims. The process to use this tool to analyze the data based on the natural relationship or resemblance between items. The Objective of this tools is to organize a large group of items into natural sets to look for relationships to elevate the individual items to a higher level of indenture for further observation and analysis [37].

Based on the urgency and the importance of customer consideration to buy paper-notebook, the researcher chose most urgent verbatim that told by most of the respondents and gathered each verbatim with the same relations and then classified each group. Each group also had a name based on its components relation. So based on the relation of each verbatim, the researcher named it cover design, cover type, cover design, and features.

Then the researcher drew a map out the logical or sequential links among related items called The Interrelationship Digraph. This tool is a companion process 
to the Affinity Diagram to trace logic patterns through the clusters. The purpose of this tool is to draw the logical connections between the groupings of the Affinity Diagram. The Affinity Diagram allows initial creative patterns to emerge, but the Interrelationship Diagraph lets logical patterns to become apparent.

\section{Tree Diagram}

The Tree Diagram is a logic-based, top-down hierarchical branching tool to structure language data into sequential dendritic logic paths. The objective of this tool is to organize a large group of items into a logic flow based on stimulus and response. The purpose of this tool is to provide a check on the Affinity Diagram. A companion process to the Affinity Diagram to enhance the completeness of the VOC database and structure [37]. Hence, the researcher turned each verbatim in the Affinity Diagram into several feasible features. Moreover, to enhance the completeness of the VOC database and structure, the researcher then drew the Tree Diagram based on the Affinity Diagram. The Tree Diagram will give a better logic flow based on stimulus and response. The Tree Diagram will breakdown the groups of attributes that influenced the paper-notebook design and each level of the attributes. Below is the Tree Diagram of the voice of customer regarding paper-notebook design.

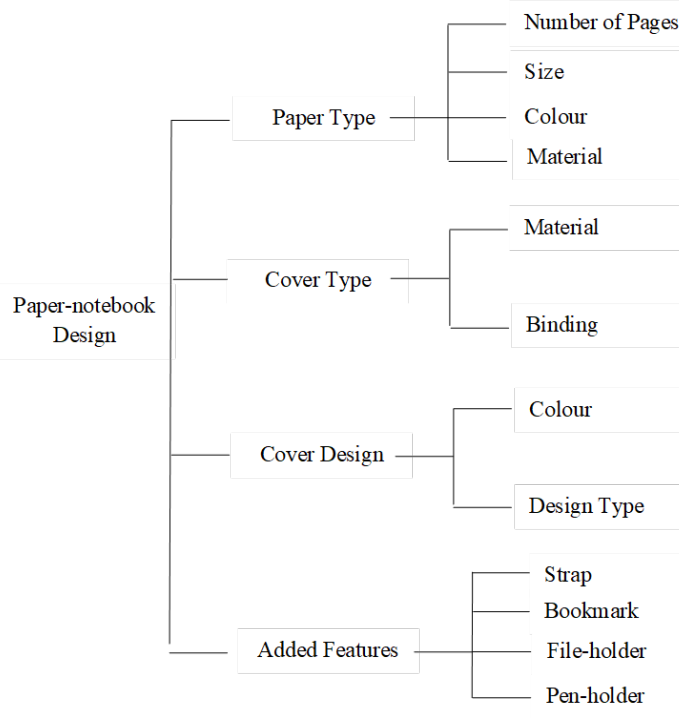

Fig. 3. Tree Diagram

From the result of the Interrelationship Diagraph, the researcher processed the re-worded customer verbatim into one word that explained the whole statement. Most of it becomes paper-notebook features. For example, the researcher translated customer re-worded customer verbatim "Dislike a heavy paper-notebook" into the number of pages and size because the weight of paper-notebook caused by its number of pages and size.

The result of the Tree Diagram then transformed into products attributes and level that will be quantified by Conjoint Analysis. However, all respondents agree to have A5 sized paper-notebook with beige or yellowish colored paper-notebook with $80-100$ pages of papers. Hence the number of pages, size and color did not input into Conjoint
Analysis. Below is the table of the product's level that surveyed and ranked:

TABLE 2: PAPER-NOTEBOOK'S ATTRIBUTES AND LEVEL

\begin{tabular}{|c|c|c|c|}
\hline \multirow{22}{*}{$\begin{array}{l}\text { Paper- } \\
\text { notebook }\end{array}$} & Groups/Cluster & Attributes & Levels \\
\hline & \multirow{3}{*}{ Paper Type } & \multirow{3}{*}{ Material } & Striped \\
\hline & & & Soft \\
\hline & & & Hard \\
\hline & \multirow{5}{*}{ Cover Type } & \multirow{2}{*}{ Material } & Softcover \\
\hline & & & Hardcover \\
\hline & & \multirow{3}{*}{$\begin{array}{l}\text { Book } \\
\text { Binding }\end{array}$} & Stitched \\
\hline & & & Glued \\
\hline & & & Spiral \\
\hline & \multirow{5}{*}{ Cover Design } & \multirow[b]{2}{*}{ Color } & Dark Colors \\
\hline & & & $\begin{array}{l}\text { Pastel } \\
\text { Colors }\end{array}$ \\
\hline & & \multirow{3}{*}{$\begin{array}{l}\text { Design } \\
\text { Type }\end{array}$} & Quotes \\
\hline & & & Gradient \\
\hline & & & Cartoon \\
\hline & \multirow{8}{*}{$\begin{array}{l}\text { Added } \\
\text { Features }\end{array}$} & \multirow{2}{*}{ Bookmark } & Yes \\
\hline & & & No \\
\hline & & \multirow{2}{*}{ Strap } & Yes \\
\hline & & & No \\
\hline & & \multirow{2}{*}{ File-holder } & Yes \\
\hline & & & No \\
\hline & & \multirow{2}{*}{ Pen-holder } & Yes \\
\hline & & & No \\
\hline
\end{tabular}

\section{Socio-Demographic of Respondents}

From the 196 validated respondents, all of them is a female. This data is in line with the sample size determined by the researcher. Hence, the other data from the survey is corresponding with the sample size needed. Also, 59.2\% of it with 116 respondents are around 20 until 21 years old females. Thirty-one respondents are around 17 until 19 years old, and 15 respondents are around 22 until 23 years old. The remaining four respondents are around 24 until 25 years old. All of them domiciled in Bandung; hence, the data is in line with the sample size determined by the researcher. Thus, the rest of the result of the survey is corresponding with the sample size needed. The total respondents of this research are dominated by female college students that come from Unpad, ITB, and UPI. Forty-five respondents come from Unpad, and the total respondents from each UPI and ITB are 41 respondents.

Furthermore, the rest of the respondents come from several universities in Bandung such as Itenas, Unpas, Unisba, Maranatha, Polban, and other universities. Besides, Eighty-one respondents choose Rp.50,000 as their maximum budget to buy a notebook, but 39 respondents choose Rp.100,000. Even 15 respondents choose more than Rp.100,000 as their budget. The respondents' budget varies, but most of the respondents choose the budget that lower than Rp.100,000. Moreover, Rp.50,000 is the most chosen maximum budget to buy a paper-notebook.

\section{E. Conjoint Analysis}

The conjoint analysis did after the voice of the customer captured. Before conducting the survey, the researcher 
generated the orthogonal design profile based on the chosen attributes and level using SPSS.

a. Orthogonal Design

TABLE 3: ORTHOGONAL DESIGN

\begin{tabular}{c|c|c}
\hline \multicolumn{3}{|c}{ Paper Type Card List } \\
\hline $\begin{array}{c}\text { CARD } \\
\text { ID }\end{array}$ & $\begin{array}{c}\text { Paper } \\
\text { Material 1 }\end{array}$ & $\begin{array}{c}\text { Paper } \\
\text { Material 2 }\end{array}$ \\
\hline 1 & Striped & Striped \\
\hline 2 & Plain & Striped \\
\hline 3 & Dotted & Striped \\
\hline 4 & Striped & Plain \\
\hline 5 & Plain & Dotted \\
\hline 6 & Dotted & Plain \\
\hline 7 & Dotted & Dotted \\
\hline 8 & Striped & Dotted \\
\hline 9 & Plain & Plain \\
\hline \hline
\end{tabular}

\begin{tabular}{c|c|c}
\multicolumn{3}{|c|}{ Cover Type Card List } \\
\hline Card ID & $\begin{array}{c}\text { Cover } \\
\text { Material }\end{array}$ & Book Binding \\
\hline 1 & Soft & Spiral \\
\hline 2 & Hard & Glued \\
\hline 3 & Soft & Glued \\
\hline 4 & Soft & Stitched \\
\hline 5 & Hard & Stitched \\
\hline \multicolumn{3}{c}{ Cover Design Card List }
\end{tabular}

\begin{tabular}{c|c|c}
\hline Card ID & Cover Color & $\begin{array}{c}\text { Cover Design } \\
\text { Type }\end{array}$ \\
\hline 1 & Dark & Cartoon \\
\hline 2 & Pastel & Quotes \\
\hline 3 & Dark & Quotes \\
\hline 4 & Dark & Gradient \\
\hline 5 & Pastel & Gradient \\
\hline 6 & Pastel & Cartoon \\
\hline
\end{tabular}

\begin{tabular}{c|c|c|c|c}
\hline $\begin{array}{c}\text { Card } \\
\text { ID }\end{array}$ & $\begin{array}{c}\text { Strap } \\
\text { Feature }\end{array}$ & $\begin{array}{c}\text { Bookmark } \\
\text { Feature }\end{array}$ & $\begin{array}{c}\text { File- } \\
\text { holder } \\
\text { Features }\end{array}$ & $\begin{array}{c}\text { Pen- } \\
\text { holder } \\
\text { Feature }\end{array}$ \\
\hline 1 & No & No & Yes & No \\
\hline 2 & Yes & Yes & Yes & Yes \\
\hline 3 & No & Yes & No & No \\
\hline 4 & Yes & No & No & No \\
\hline 5 & No & No & Yes & Yes \\
\hline 6 & No & Yes & No & Yes \\
\hline 7 & Yes & Yes & Yes & No \\
\hline 8 & Yes & No & No & Yes \\
\hline
\end{tabular}

From the attributes and levels from Table 3, the researcher decided to survey the preference of customers about each aspect (paper types, cover types, cover design, and added features). For the paper types, it generated nine profiles (card). Moreover, for the cover types, it generated six profiles (card). For the cover design, it generated six profiles (card). Furthermore, for the added features, it generated eight profiles (card). Below is the generated orthogonal design.

\section{b. Reversals}

Reversals mean that there is a subject whose preference showed the opposite of the expected relationship. The result from the conjoint analysis indicates that there are no reversals in each aspect surveyed. Thus, the respondents' preference shows the similarity of the expected relationship.

c. Coefficient

TABLE 4: PEARSON'S R COEFFICIENT

\begin{tabular}{l|c|c}
\hline \multicolumn{3}{|c}{ Pearson's R Coefficient } \\
\hline & Value & Significance \\
\hline Paper Types & 0.903 & 0.000 \\
\hline Cover Types & 0.946 & 0.002 \\
\hline Cover Design & 0.968 & 0.001 \\
\hline Added Features & 0.968 & 0.001 \\
\hline
\end{tabular}

From Pearson's R correlation results in a table below, it concluded that model utility and actual utility are correlated positively since each Pearson's R score of each aspect are less than 0.05 (significance level). It proves the continuation of a strong relationship between the model utility and the actual utility. Furthermore, it means that there is a correlation between the estimated value and the actual preferences.

\section{d. Utility Result}

TABLE 5: UTILITY RESULT (Cont.)

\begin{tabular}{|c|c|c|c|}
\hline \multicolumn{4}{|c|}{ Paper Type Utilities } \\
\hline & & Utility Estimate & Std. Error \\
\hline \multirow{3}{*}{ Paper2 } & Striped & .621 & .191 \\
\hline & Plain & .015 & .191 \\
\hline & Dotted & -.636 & .191 \\
\hline \multirow{3}{*}{ Paper1 } & Striped & -.061 & .191 \\
\hline & Plain & .323 & .191 \\
\hline & Dotted & -.262 & .191 \\
\hline \multicolumn{2}{|l|}{ (Constant) } & 5.000 & .135 \\
\hline \multicolumn{4}{|c|}{ Cover Type Utilities } \\
\hline & & Utility Estimate & Std. Error \\
\hline \multirow{2}{*}{ Material } & Softcover & -.287 & .096 \\
\hline & Hardcover & .287 & .096 \\
\hline \multirow{3}{*}{ Binding } & Glued & -.089 & .135 \\
\hline & Stitched & -.278 & .135 \\
\hline & Spiral & .367 & .135 \\
\hline \multicolumn{2}{|l|}{ (Constant) } & 3.500 & .096 \\
\hline \multicolumn{4}{|c|}{ Cover Design Utilities } \\
\hline & & Utility Estimate & Std. Error \\
\hline \multirow{2}{*}{ Color } & Dark & .082 & .112 \\
\hline & Pastel & -.082 & .112 \\
\hline \multirow{3}{*}{$\begin{array}{l}\text { Design- } \\
\text { Type }\end{array}$} & Quotes & .827 & .159 \\
\hline & Gradient & -.230 & .159 \\
\hline & Cartoon & -.597 & .159 \\
\hline \multicolumn{2}{|l|}{ (Constant) } & 3.500 & .112 \\
\hline
\end{tabular}


Table 5. UTILITY RESULT (Cont.)

\begin{tabular}{|c|c|c|c|}
\hline \multicolumn{4}{|c|}{ Added Features Utilities } \\
\hline & & Utility Estimate & Std. Error \\
\hline \multirow{2}{*}{ Strap } & Yes & .058 & .336 \\
\hline & No & -.058 & .336 \\
\hline \multirow{2}{*}{ Bookmark } & Yes & .278 & .336 \\
\hline & No & -.278 & .336 \\
\hline \multirow{2}{*}{$\begin{array}{l}\text { File- } \\
\text { Holder }\end{array}$} & Yes & .446 & .336 \\
\hline & No & -.446 & .336 \\
\hline \multirow{2}{*}{$\begin{array}{l}\text { Pen- } \\
\text { Holder }\end{array}$} & Yes & -.262 & .336 \\
\hline & No & .262 & .336 \\
\hline \multicolumn{2}{|l|}{ (Constant) } & 4.500 & .336 \\
\hline
\end{tabular}

One of the results from the conjoint analysis is utility or part-worth. Utility (part-worth) scores and their standard errors for each factor level are the determinants of the most preferred profile by respondents. Higher utility values indicate a greater preference. After that, the resulted utilities were calculated to get the total utility score for each profile.

\section{e. $\quad$ Total Utility Scores}

Since the utilities are all expressed in a standard unit, they can be added together with constant to give the total utility of any combination. The following mathematical equation may represent the basic model in the conjoint analysis:

$U(x)=\sum_{i=1}^{m} \sum_{j=1}^{k_{i}} \beta_{i j} x_{i j+} \varepsilon_{i j}$

Description:

$U(X)=$ total utilities

$k_{i}=$ level $j$ of attribute $\mathrm{i}$

$m=$ number of attributes

$x_{i j}=$ dummy variable of attribute $i$ level $j$ (value of 1 when

the related level emerging and if otherwise is 0 )

$\beta_{i j}=$ part-worth or utility value of attribute $i$ level $j$

$\varepsilon_{i j}=$ stochastic error value or constant.

Each profile from four groups calculated, and a profile with the highest score among other profiles considered as the most preferred profile by respondents. Below is the calculation from paper types, cover type, cover design and added features:
- Paper Type

TABLE 6: PAPER TYPE UTILITY SCORE

\begin{tabular}{c|l|l|l}
\multicolumn{4}{c}{ Paper Type Utility Scores } \\
\hline 1 & Striped & Striped & 5.560 \\
\hline $\mathbf{2}$ & Striped & Plain & $\mathbf{5 . 9 4 4}$ \\
\hline 3 & Striped & Dotted & 5.359 \\
\hline 4 & Plain & Striped & 4.954 \\
\hline 5 & Dotted & Plain & 4.687 \\
\hline 6 & Plain & Dotted & 4.753 \\
\hline 7 & Dotted & Dotted & 4.102 \\
\hline 8 & Dotted & Striped & 4.303 \\
\hline 9 & Plain & Plain & 5.338 \\
\hline
\end{tabular}

Based on the calculation of each profile with the partworth or utility value, striped paper with plain paper has the highest score with 5.944 total utility. Hence, based on the calculation, the mixed paper between striped paper and plain paper is the most preferred paper type by respondents.

- $\quad$ Cover Types

TABLE 7: COVER TYPE UTILITY SCORE

Cover Type Utility Scores

\begin{tabular}{c|l|l|l}
\hline 1 & Softcover & Spiral & 3.580 \\
\hline 2 & Hardcover & Glued & 3.698 \\
\hline 3 & Softcover & Glued & 3.123 \\
\hline 4 & Softcover & Stitched & 2.935 \\
\hline 5 & Hardcover & Stitched & 3.698 \\
\hline $\mathbf{6}$ & Hardcover & Spiral & $\mathbf{4 . 1 5 5}$ \\
\hline
\end{tabular}

The calculation of cover type utility score for each profile result with the part-worth or utility value, it shows that hardcover with spiral binding has the highest score among other profiles with 4.155 total utility score. It indicates that hardcover with the spiral binding is the most preferred profile by respondents.

\section{- Cover Design}

TABLE 8: COVER DESIGN UTILITY SCORES

\begin{tabular}{c|l|l|l}
\hline \multicolumn{4}{c}{ Cover Design Utility Scores } \\
\hline 1 & Dark Color & Cartoon Style & 2.985 \\
\hline 2 & Pastel Color & Quotes Style & 4.245 \\
\hline $\mathbf{3}$ & Dark Color & Quotes Style & $\mathbf{4 . 4 0 8}$ \\
\hline 4 & Dark Color & Gradient Style & 3.352 \\
\hline 5 & Pastel Color & Gradient Style & 3.189 \\
\hline 6 & Pastel Color & Cartoon Style & 2.821 \\
\hline
\end{tabular}

The combination of dark color with quotes design style 
or quotes as the main object of design has the highest score with 4.408 total utility score. It means that most of the respondents prefer dark color design with quotes as the main content for cover design.

\section{- $\quad$ Added Features}

TABLE 9: PEARSON'S R COEFFICIENT

\begin{tabular}{l|l|l|l|l|l}
\hline \multicolumn{7}{c}{ Added Features Utility Score } \\
\hline 1 & No strap & No Bookmark & File-holder & No Pen-holder & 4.349 \\
\hline 2 & Strap & Bookmark & File-holder & Pen-holder & 5.021 \\
\hline 3 & No strap & Bookmark & No File-holder & No Pen-holder & 4.536 \\
\hline 4 & Strap & No bookmark & No File-holder & No Pen-holder & 4.095 \\
\hline 5 & No strap & No bookmark & File-holder & Pen-holder & 4.349 \\
\hline 6 & No strap & Bookmark & No File-holder & Pen-holder & 4.013 \\
\hline $\mathbf{7}$ & Strap & Bookmark & File-holder & No Pen-holder & $\mathbf{5 . 5 4 4}$ \\
\hline 8 & Strap & No bookmark & No File-holder & Pen-holder & 3.572 \\
\hline
\end{tabular}

Based on the result of the calculation for each profile, profile number seven with strap, bookmark, and file-holder as the added features have the highest score with 5.544 total utility score. Hence, it considers that the combination among strap, bookmark, and file-holder is the most preferred by the respondents.

\section{CONCLUSION AND DISCUSSION}

The purpose of this research is to discover the voice of the customer (VOC) regarding a paper-notebook and process it into several features and create a new paper-notebook design based on customer preference. According to the data analysis of the semi-interview and the questionnaire result using SPSS software, it discovered that one of the preferable paper-notebook features is a yellowish paper. Moreover, in one paper-notebook, the respondents prefer a mixed paper between striped and plain paper. The respondents also prefer an A5 (14,8 x $21 \mathrm{~cm})$ sized paper-notebook with hardcover and spiral binding. Moreover, for the cover design, the respondents prefer a dark color with quotes design as the design type. For the added features, the respondents prefer strap, bookmark (divided section), and file-holder.

Based on the most preferred features above, the researcher designed paper-notebook design and created a Minimum Viable Product for the result of this analysis. Several pictures of the products placed below:
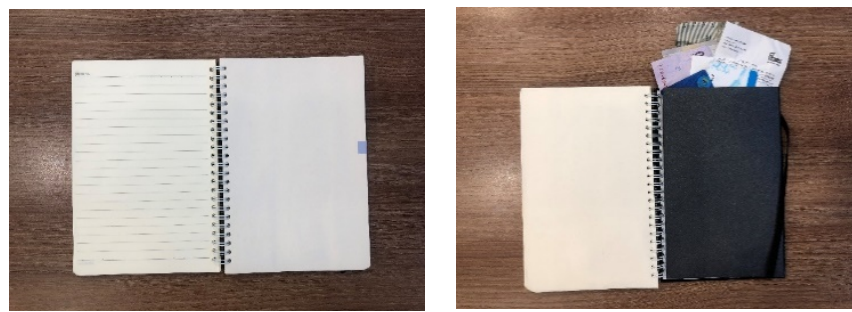

Fig. 4. Minimum Viable Product

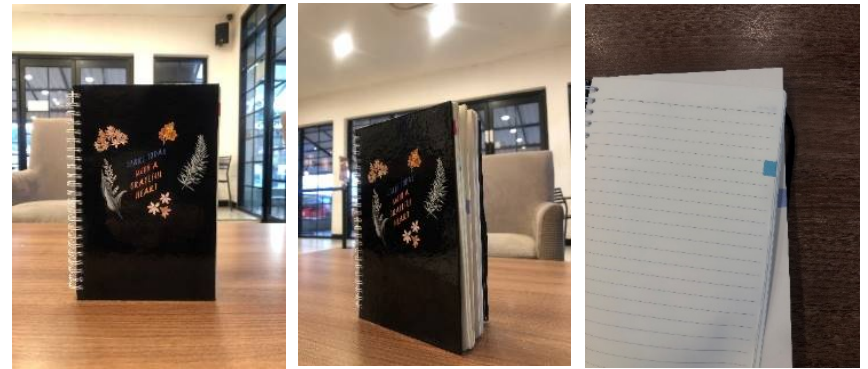

Fig. 5. Minimum Viable Product

The researcher recommends a paper-notebook to have several additional features to be able to have a uniqueness and difference from any other product in the market. The additional features can be utilized are strap, file-holder, and bookmark. Any other features might be added according to customer needs. The researcher also encourages to hire a professional designer to create a better cover-design to be able to meet customer preference.

The next step also could be taken to verify the conjoint result by doing Minimum Viable Product (MVP) test that consists of Build-Measure-Learn loop based on the Lean Startup theory. The researcher could test both valuehypothesis to test customer willingness to buy the product and growth-hypothesis to test whether the customer has a willingness to recommend the product or not.

Also, this research was limited to female college-student in Bandung and the questionnaire focus was on several attributes that combined just by few attributes and level in the same cluster. Further research could be conducted by 
utilizing cluster analysis by researching broader segments, to discover more market segments and the best product for each segment. Moreover, further study about papernotebook's features better to do the orthogonal design that combined all features and unlocks the paper-notebook's profile as a complete package. Then the researcher could survey the orthogonal design result (paper-notebook's profile), and the respondents rank paper-notebook's profile based on their preferences. This researcher will result in the most preferred paper-notebook profile as a whole product.

\section{REFERENCES}

[1] Arminana, P., Trapp, R., Aguilar, E., \& Ramly, R. (2013). Moleskine Report.

[2] Bharadwaj, N., Nevin, J. R., \& Wallman, J. P. (2012). Explicating Hearing the Voice of the Customer as Explicating Hearing the Voice of the Customer as its Consequences.

[3] Cambridge. (n.d.). Cambridge Dictionary. Retrieved from dictionary.cambridge.org:

https://dictionary.cambridge.org/dictionary/english/notebook

[4] Carulli, M., Bordegoni , M., \& Cugini, U. (2012). An approach for capturing the Voice of the Customer based on Virtual Prototyping.

[5] Carulli, M., Bordegoni, M., \& Cugini, U. (2012). An Approach for Capturing the Voice of the Customer on Virtual Prototyping.

[6] Carwford, M., \& Benedetto, A. D. (2015). New Products Management Eleven Edition. McGraw-Hill International Edition.

[7] Chell, E., \& Baines, E. (2010). Networking, Entrepreneurship and Microbusiness Behaviour.

[8] Cooper, R. G. (2018). The drivers of success in new-product development.

[9] Corporation, I. (2012). IBM SPSS Conjoint 21.

[10] Crawford, M., \& Benedetto, A. D. (2015). New Products Management Eleventh Edition. McGraw-Hill International Edition.

[11] Creswell, J. W. (1998). Qualitative Inquiry and Research Design: Choosing among Five Tradition.

[12] Fallon, S. (2014). A Conjoint Analysis of Reader Preference for the Layout of Tablet Editions of Magazines.

[13] Gaskin, S. P., Griffin, A., Hauser, J. R., Katz, G. M., \& Klein, R. L. (2011). Voice of the Customer.

[14] Gawthrop, J., \& Gopal, S. (2017). Streamlining the Voice of the Customer; A study exploring Voice of the Customer at Company X.

[15] Green, P. E., Krieger, A. M., \& Wind, Y. (2001). Thirty Years of Conjoint Analysis: Reflections and Prospects.

[16] Grunert, K., \& Trijp, H. v. (2014). Consumer-Oriented New Product Development.

[17] Hakim, A. S. (2018). BUYING BEHAVIOR TOWARD PAPER NOTEBOOK.

[18] Hauser, J. R., \& Rao, V. R. (2002). Conjoint Analysis, Related Modeling, and Applications.

[19] Isaias, P., Miranda, P., \& Pifano, S. (2015). An empirical study on computer and paper-based resources: Are they competitive or complementary means? IADIS International Journal On Computer Science and Information Systems.

[20] Jr., J. F., Black, W. C., Babin, B. J., \& Anderson, R. E. (2014). Multivariate Data Analysis Seventh Edition. Pearson Education Limited.

[21] Kemendikbu. (2016). KBBI Daring. Retrieved from kbbi.kemendikbud.go.id: https://kbbi.kemdikbud.go.id/entri/buku

[22] Kleef, E. v., Trijp, H. C., \& Luning, P. (2004). Consumer research in the early stages of new product development: a critical review of methods and techniques.

[23] Kosasih, W., Salomon, L. L., \& Hutomo, R. (2017). Using Conjoint Analysis and Cluster Analysis in Developing New Product for Micro, Small and Medium Enterprises (SMEs) Based on Customer Preferences (Case Study: Lampung Province's Banana Chips).

[24] Kotler, P., \& Armstrong, G. (2014). Principles of Marketing. Pearson.

[25] Kruse, J. (n.d.). How to Start a Clothing Company Lean Startup Guide.

[26] Lee, H., Han, J., \& Suh, Y. (2014). Gift or threat? An examination of voice of the customer: The case.

[27] Lenarduzzi, V., \& Taibi, D. (2016). MVP Explained: A Systematic Mapping Study on the Definitions of Minimal Viable Product.

[28] Oyatoye, E. O., Otike-Obaro, A. E., \& Ezeoke. (n.d.). Using Conjoint Analysis to Study the Factors Important to University Students in Nigeria When They Select a Laptop Computer.
[29] Prasojo, F., \& Indriani, M. T. (2015). NEW PRODUCT DEVELOPMENT FOR A STARTUP COMPANY

[30] Pullmana, M. E., Mooreb, W. L., \& Wardell, D. G. (2002). A comparison of quality function deployment and conjoint analysis in new product design.

[31] Ries, E. (2009, August 3). Minimum Viable Product: a guide. Retrieved from Startup Lesson Learned: http://www.startuplessonslearned.com/2009/08/minimum-viableproduct-guide.html

[32] Ries, E. (2011). The Lean Startup.

[33] Rini, A. S. (2018, May 9). Manufaktur. Retrieved from bisnisekonomi.com:

https://ekonomi.bisnis.com/read/20180509/257/793560/pasar-bukutulis-masih-menjan

[34] Saeed, R., Lodhi, R. N., Munir, J., Riaz, S., Dustgeer, F., \& Sami, A. (2003). The Impact of Voice of Customer on New Product Development.

[35] Saunders, M., Thornhill, A., \& Lewis, P. (2019). Research Methods for Business Students. In M. Saunders, A. Thornhill, \& P. Lewis, Research Methods for Business Students (p. 139). Pearson Education Limited.

[36] Sceulovs, D., \& Sarkane, E. G. (2012). Classification of Micro and Small Enterprises.

[37] Schreiner, M. (2001). Microenterprise in the First and Third Worlds.

[38] Shillito, M. L. (2001). Acquiring, Processing, and Deploying Voice of The Customer. St. Lucie Press.

[39] Speight, K. C., Schiano, A., Harwood, W., \& Drake, M. (2019). Consumer insights on prepackaged Cheddar cheese shreds using focus groups, conjoint analysis, and qualitative multivariate analysis.

[40] Ulrich, K. T., \& Eppinger, S. D. (2012). Product Design and Development.

[41] Vanalli, S., \& Cziulik, C. (2003). Seven Steps to the Voice of the Customer.

[42] Voleti, S., Srinivasan, V., \& Ghosh, P. (2016). An approach to improve the predictive power of choice-based. International Journal of Research in Marketing.

[43] Wang, C.-H., \& Shih, C.-W. (2013). Integrating conjoint analysis with quality function deployment to carry out customer-driven concept development for ultrabooks.

[44] Yoo, D.-i., \& Ohta, H. (1994). Optimal Product-Planning for New Multiattribute Products Based on Conjoint Analysis.

[45] Zhu, Q. (2007). CONSUMER PREFERENCES FOR INTERNET SERVICES: A CHOICE-BASED CONJOINT STUDY.

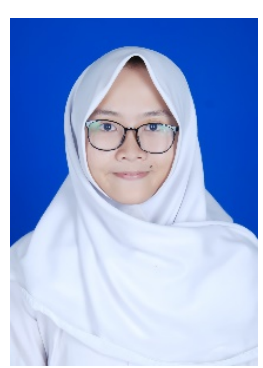

Puteri Annisa Tsamrotul Fuadah was born in Sumedang on September $18^{\text {th }}$ in 1998. When writing this researcher, she was a final year student of bachelor of entrepreneurship of School of Business and Management of Institut Teknologi Bandung. Also, she has business experience in the stationery industry.

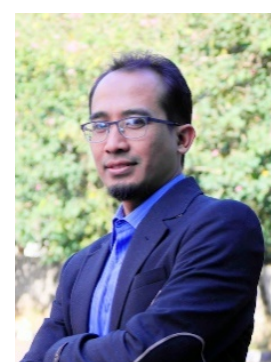

Dr. rer. Pol.Eko Agus Prasetio, ST., M.B.A, is a full-time lecturer at School of Business and Management, Institut Teknologi Bandung (SBMITB) since 2011. He obtained his Ph.D. from the Faculty of Economics and Business Administration, Friedrich Schiller University (FSU), Jena, Germany. He investigated the influence of network effects and consumers' network structures on the likelihood of technological disruption. During his Ph.D. study, he joined GK-EIC or Graduate College Economics of Innovative Change, a research group bringing together the Max-Planck Institute (MPI) and FSU Jena. His MBA is from Nyenrode Business University, Netherlands; the program included an executive marketing module in Kellogg School of Management, Northwestern University, USA. He earned his first degree in Engineering Physics from ITB. Before joining SBM-ITB, he had more than ten years professional experience in innovation and new product development holding positions in manufacturing companies in Netherlands, Japan and Indonesia. His research interests are technological acceptance and diffusion of disruptive innovation, including social network analysis and agent-based modeling, and knowledge spillover of entrepreneurship. 